\section{IMI's collaborative chemistry}

\section{By Chris Cain, Senior Writer}

Europe's Innovative Medicines Initiative has launched seven new publicprivate partnerships with a total budget of $€ 237$ million ( $\$ 313$ million). In contrast to many of the organization's disease-focused projects, three of the new consortia are taking a drug-centric approach that includes plans to optimize small molecule binding kinetics and develop new delivery systems for RNA- and protein-based therapeutics.

The projects comprise the fourth wave of initiatives launched by IMI since its 2008 founding (see Table 1, "IMI's fourth call"). In total, the organization now manages 37 ongoing projects with a total budget of more than $\$ 1$ billion.
Hugh Laverty, a senior scientific project manager at IMI, told SciBX that the push for projects focused on drug optimization and delivery was driven by European Federation of Pharmaceutical Industries and Associations (EFPIA) members seeking to collaborate on solutions to common problems that crop up in drug development regardless of therapeutic area.

"When companies are looking at some problems they face internally there is clearly a focus on certain areas like Alzheimer's disease or stem cell biology, and we have projects that cover those. The problems being addressed by these projects are faced at all stages of drug development, from lead identification to formulation to manufacturing," said Laverty.

The new consortia that seek to optimize drug properties and delivery methods are the Collaboration on the Optimization of Macromolecular Pharmaceutical Access to Cellular Targets (COMPACT) led by Sanofi, Kinetics for Drug Discovery (K4DD) led by Bayer AG and Oral Biopharmaceutics Tools (ORBITO) led by AstraZeneca plc.

"These topics are the bread and butter of the pharmaceutical companies. If we see progress in developing new models or in silico methods to predict or measure oral bioavailability or kinetics of drug binding more accurately, you have the potential to change the way drugs are discovered and developed," said Laverty.

\begin{tabular}{|c|c|c|c|}
\hline Project title & EFPIA participants ${ }^{A}$ & EFPIA in kind & IMI \\
\hline $\begin{array}{l}\text { CHEM21 (Chemical } \\
\text { Manufacturing Methods } \\
\text { for the } 21 \text { st Century } \\
\text { Pharmaceutical Industries) }\end{array}$ & $\begin{array}{l}\text { GlaxoSmithKline plc (LSE:GSK; NYSE:GSK); Bayer AG (Xetra:BAYN); } \\
\text { Johnson \& Johnson (NYSE:JNJ); Orion Corp. (HSE:ORNAV; HSE:ORNBV); } \\
\text { Pfizer Inc. (NYSE:PFE); Sanofi (Euronext:SAN; NYSE:SNY) }\end{array}$ & $€ 9.8(\$ 13.0)$ & $€ 13.6(\$ 18)$ \\
\hline $\begin{array}{l}\text { COMPACT (Collaboration } \\
\text { on the Optimization } \\
\text { of Macromolecular } \\
\text { Pharmaceutical Access to } \\
\text { Cellular Targets) }\end{array}$ & $\begin{array}{l}\text { Sanofi; Boehringer Ingelheim GmbH; Bayer; Johnson \& Johnson; } \\
\text { GlaxoSmithKline; Merck KGaA (Xetra:MRK); Novo Nordisk A/S (CSE:NVO; } \\
\text { NYSE:NVO); Pfizer }\end{array}$ & $€ 10.2(\$ 13.5)$ & $€ 16.6(\$ 22)$ \\
\hline $\begin{array}{l}\text { EMIF (European Medical } \\
\text { Information Framework) }\end{array}$ & $\begin{array}{l}\text { GlaxoSmithKline; Amgen Inc. (NASDAQ:AMGN); Boehringer Ingelheim; } \\
\text { Roche (SIX:ROG; OTCQX:RHHBY); Johnson \& Johnson; Novo Nordisk; } \\
\text { Pfizer; Servier; UCB Group (Euronext:UCB) }\end{array}$ & $€ 24.4(\$ 32.3)$ & $€ 24.1(\$ 31.9)$ \\
\hline $\begin{array}{l}\text { K4DD (Kinetics for Drug } \\
\text { Discovery) }\end{array}$ & $\begin{array}{l}\text { Bayer; AstraZeneca; Roche; GlaxoSmithKline; Johnson \& Johnson; } \\
\text { Merck KGaA; Sanofi }\end{array}$ & $€ 8.3(\$ 11.0)$ & $€ 9.8(\$ 13.0)$ \\
\hline $\begin{array}{l}\text { ORBITO (Oral } \\
\text { Biopharmaceutics Tools) }\end{array}$ & $\begin{array}{l}\text { AstraZeneca; Abbott Laboratories (NYSE:ABT); Bayer; Boehringer } \\
\text { Ingelheim; GlaxoSmithKline; H. Lundbeck; Johnson \& Johnson; } \\
\text { Merck \& Co. Inc. (NYSE:MRK); Novartis AG (NYSE:NVS; SIX:NOVN); } \\
\text { Orion; Pfizer; Sanofi }\end{array}$ & $€ 9(\$ 11.9)$ & $€ 11.5(\$ 15.2)$ \\
\hline $\begin{array}{l}\text { STEMBANCC (Stem Cells } \\
\text { for Biological Assays of } \\
\text { Novel Drugs and Predictive } \\
\text { Toxicology) }\end{array}$ & $\begin{array}{l}\text { Roche; Abbott; Boehringer Ingelheim; Eli Lilly; Johnson \& Johnson; Merck KGaA; } \\
\text { Novo Nordisk; Orion; Pfizer; Sanofi }\end{array}$ & $€ 26(\$ 34.4)$ & $€ 21(\$ 27.8)$ \\
\hline
\end{tabular}


Ekkehard Leberer, a senior director at Sanofi and the EFPIA coordinator of COMPACT, told SciBX that the focus of the initiative he is overseeing is on developing new methods to specifically deliver RNA- and protein-based therapeutics to tissues including the lung and brain. This will include synthesizing and testing new liposome delivery formulations, polymeric nanoparticle carriers, cell-penetrant peptide carriers, modified oligonucleotides, exosomes and microneedle delivery systems.

He said the consortium is not interested in refining or characterizing existing formulations. "Many of our partners are working on liposomes and already have systems in place, but we are not interested in testing those systems. We want to develop new systems and new ideas, and we expect the academic postdocs and students will be involved in generating those ideas," he said.

Although the consortium will look to academia for some fresh thinking, Leberer said the industry members will help keep the consortium focused on clinically feasible projects. "We are not just developing tools for the sake of getting publications. We have given guidance to our partners from the beginning that our goal is to develop a drug. Any formulation needs to be scalable and translatable into a manufacturing process, and industry can provide that input," he said.

Unlike COMPACT, the ORBITO and K4DD projects are not aiming to develop new drug delivery modalities. Instead, those two consortia seek to better understand how conventional small molecules are absorbed into the bloodstream and engage their targets.

ORBITO aims to define the physicochemical formulation and physiological factors that affect small molecule oral bioavailability. Laverty said this will be accomplished by sharing existing compound data accumulated by EFPIA participants, generating new complementary data and testing those compounds in new models developed by the consortium. These new models will encompass in vitro, in vivo and in silico tools to predict drug oral bioavailability.

AstraZeneca is lead EFPIA coordinator of ORBITO and did not respond to interview requests.
Anke Müller-Fahrnow, VP and head of lead discovery at Bayer and the EFPIA coordinator of K4DD, said her initiative is focused on improving the understanding of how small molecules interact with their targets.

"We are increasingly realizing that in vitro tests in a research lab may not accurately reflect the in vivo situation in a patient. For instance, common in vitro equilibrium studies may not be completely predictive in an in vivo system. Two similar-affinity drugs may have very different residence times-the actual lifetime of the drug-receptor complex-which in turn can have an effect on efficacy and also side effects," she said.

To better understand drug binding kinetics, the initiative will begin by developing new techniques that can be used to characterize the binding of compounds within cells, particularly against targets tough to characterize in vitro, such as membrane-bound proteins. Müller-Fahrnow said insights from these studies will then be applied to in vivo pharmacology and physiology studies.

She added that the scientific community often underestimates the importance of binding kinetics in drug discovery. "Raising the awareness for kinetic parameters might mean that by the end of the consortium's lifetime in 2017, editors and reviewers for scientific journals could routinely ask for kinetic data and industry could do more to adopt strategies to learn about kinetics in the very early stages of the drug discovery process," she said.

Cain, C. SciBX 6(3); doi:10.1038/scibx.2013.51

Published online Jan. 24, 2013

COMPANIES AND INSTITUTIONS MENTIONED

AstraZeneca plc (LSE:AZN; NYSE:AZN), London, U.K.

Bayer AG (Xetra:BAYN), Leverkusen, Germany

European Federation of Pharmaceutical Industries and

Associations, Brussels, Belgium

Innovative Medicines Initiative, Brussels, Belgium

Sanofi (Euronext:SAN; NYSE:SNY), Paris, France 